\title{
Emergomycosis, an Emerging Systemic Mycosis in Immunocompromised Patients: Current Trends and Future Prospects
}

\author{
Arghadip Samaddar* and Anuradha Sharma \\ Department of Microbiology, All India Institute of Medical Sciences, Jodhpur, India
}

Recently, the global emergence of emergomycosis, a systemic fungal infection caused by a novel dimorphic fungus Emergomyces species has been observed among immunocompromised individuals. Though initially classified under the genus Emmonsia, a taxonomic revision in 2017 based on DNA sequence analyses placed five Emmonsia-like fungi under a separate genus Emergomyces. These include Emergomyces pasteurianus, Emergomyces africanus, Emergomyces canadensis, Emergomyces orientalis, and Emergomyces europaeus. Emmonsia parva was renamed as Blastomyces parvus, while Emmonsia crescens and Emmonsia sola remained within

OPEN ACCESS

Edited by:

Zhiliang $\mathrm{Hu}$,

Nanjing Second Hospital, China

Reviewed by:

Alexandre Alanio,

Université Paris Diderot, France

Barbra Toplis,

Stellenbosch University, South Africa

${ }^{*}$ Correspondence:

Arghadip Samaddar

argha2387@gmail.com

Specialty section

This article was submitted to

Infectious Diseases - Surveillance,

Prevention and Treatment,

a section of the journal

Frontiers in Medicine

Received: 22 February 2021

Accepted: 31 March 2021

Published: 23 April 2021

Citation:

Samaddar A and Sharma A (2021)

Emergomycosis, an Emerging

Systemic Mycosis in

Immunocompromised Patients:

Current Trends and Future Prospects.

Front. Med. 8:670731.

doi: 10.3389/fmed.2021.670731 the genus Emmonsia until a taxonomic revision in 2020 placed both the species under the genus Emergomyces. However, unlike other members of the genus, Emergomyces crescens and Emergomyces sola do not cause disseminated disease. The former causes adiaspiromycosis, a granulomatous pulmonary disease, while the latter has not been associated with human disease. So far, emergomycosis has been mapped across four continents: Asia, Europe, Africa and North America. However, considering the increasing prevalence of HIV/AIDS, it is presumed that the disease must have a worldwide distribution with many cases going undetected. Diagnosis of emergomycosis remains challenging. It should be considered in the differential diagnosis of histoplasmosis as there is considerable clinical and histopathological overlap between the two entities. Sequencing the internal transcribed spacer region of ribosomal DNA is considered as the gold standard for identification, but its application is compromised in resource limited settings. Serological tests are non-specific and demonstrate cross-reactivity with Histoplasma galactomannan antigen. Therefore, an affordable, accessible, and reliable diagnostic test is the need of the hour to enable its diagnosis in endemic regions and also for epidemiological surveillance. Currently, there are no consensus guidelines for the treatment of emergomycosis. The recommended regimen consists of amphotericin B (deoxycholate or liposomal formulation) for 1-2 weeks, followed by oral itraconazole for at least 12 months. This review elaborates the taxonomic, clinical, diagnostic, and therapeutic aspects of emergomycosis. It also enumerates several novel antifungal drugs which might hold promise in the treatment of this condition and therefore, can be potential areas of future studies.

Keywords: emergomycosis, emergomyces, dimorphic fungi, endemic mycoses, AIDS-related mycosis, antifungal drug 


\section{BACKGROUND}

Fungal infections are constantly evolving with new genera and species being increasingly implicated in human diseases. Consequently, the diagnosis and management of such infections become challenging. One such infection that has been recently observed among immunocompromised individuals is attributed to a novel dimorphic fungus closely related to Emmonsia species (1). Due to taxonomic similarity, they were initially classified under the genus Emmonsia, either as Emmonsia pasteuriana or Emmonsia-like species. However, genetic sequence analysis, later on, found that these fungi belonged to a previously unknown genus and due to their recent global emergence, they were ascribed to a new genus Emergomyces and the disease was designated as emergomycosis (2).

\section{RECENT TAXONOMY AND CLASSIFICATION}

Since the 1970's, there has been an emergence of several novel fungi with phylogenetic, and morphological similarities to known members of the Ajellomycetaceae family. To resolve the phylogenetic relationships among Emmonsia and Emmonsia-like fungi, which seem to be closely related to Blastomyces spp. and to a lesser extent to other members of Ajellomycetaceae family, global collections of Emmonsia-like fungi were re-examined using concatenated sequence data of five loci: large subunit rDNA (LSU), internal transcribed spacer (ITS), $\beta$-tubulin (TUB2), elongation factor 3 (TEF3), and RNA polymerase II (rPB2) (24). This led to a taxonomic revision within the Ajellomycetaceae family in 2017, following which five Emmonsia-like fungi were placed under a separate genus Emergomyces, members of which have been associated with a fatal disseminated mycosis in Asia, Europe, Africa and North America (3). The five distinct species under the genus included Emergomyces pasteurianus, Emergomyces africanus, Emergomyces canadensis, Emergomyces orientalis, and Emergomyces europaeus $(1,3,4)$. Emmonisa parva was shifted to the genus Blastomyces as Blastomyces parvus, while Emmonsia sola and Emmonsia crescens remained in the genus Emmonsia. Initially, Emergomyces spp. were differentiated from Emmonsia spp. by the presence of small budding yeast cells instead of thick-walled non-replicating adiaspores in their thermotolerant phase $(4,5)$. However, later it became evident that species within the genus Emergomyces can present a spectrum of morphologies from budding yeast cells to adiaspores. Consequently, the genus Emmonsia was removed and Ea. sola and Ea. crescens were re-classified as Emergomyces in 2020 after further analyses (6). However, unlike other members of the genus Emergomyces, Es. crescens and Es. sola do not cause disseminated disease. The former causes adiaspiromycosis, a granulomatous pulmonary disease, while the latter has not been associated with human disease. Es. pasteurianus is the most widespread and represents the type species, while Es. africanus is one of the most frequent endemic mycosis diagnosed in South Africa. (7) The order Onygenales of Ajellomycetaceae family currently comprises of seven genera: Emergomyces, Blastomyces,
Histoplasma, Paracoccidioides, Lacazia, Emmonsiellopsis, and Helicocarpus (2, 4, 5, 8-10), as summarized in Table 1.

\section{GEOGRAPHICAL DISTRIBUTION}

To date, emergomycosis has been reported from four continents: Asia, Africa, Europe and North America (1, 2, 4). However, several authors suggest that the disease might have a global prevalence. The genus Emergomyces consists of five species: Es. pasteurianus, the type species, has been reported from Asia (China (11, 12) and India (13, 14)), Europe (Italy (15), France (16), Spain (17), and the Netherlands (18)), and Africa (Uganda (19) and South Africa (2)), Es. africanus from South Africa, (2) Zimbabwe, and Lesotho (20), Es. canadensis from Canada (Saskatchewan) and the United States (Colorado and New Mexico) (21), Es. orientalis from China (Shanxi), (22) and Es. europaeus from Germany (23). The most extensive burden of the disease has been observed among HIV-infected patients of South Africa where it has been reported from six of the nine provinces and most cases are attributed to Es. africanus (24). All South African cases of emergomycosis were diagnosed after the introduction of broad-range fungal PCR in 2013. Thus, the apparent clustering of cases and the emergence of Es. africanus in South Africa may simply represent accurate identification of the causative agent rather than introduction of a novel dimorphic fungal pathogen. There is a possibility that many cases of emergomycosis might have gone missed due to lack of awareness regarding the disease and misidentification of the causative agent. The latter hypothesis is supported by the dramatic increase in the number of cases of disseminated emergomycosis with a relative decline in the number of histoplasmosis cases in South Africa, following the introduction of molecular identification techniques $(25,26)$. All the South African cases were adults with advanced HIV disease (median CD4+ T cell count 16 cells $/ \mu \mathrm{L}$ ) and had extensive cutaneous involvement (27). Although countrylevel surveillance data is lacking, a clinical and laboratory surveillance study at public hospitals in Cape Town, South Africa, documented 17 culture proven cases of emergomycosis over a period of 15 months (28). Detection of Es. africanus DNA in 30\% of soils samples from the Western Cape Province (7) and in 10\% of air samples from Cape Town (26), indicate that the fungus might have an ecological niche. However, to date, it has not been successfully isolated in culture from the environment. Also, natural infections in animals have not yet been documented (29).

\section{VIRULENCE AND PATHOGENESIS}

Infection with Emergomyces spp. is presumed to occur through inhalation of conidia present in soil, followed by in vivo transformation to a yeast-like phase that is capable of extrapulmonary dissemination in susceptible hosts. Little is known regarding the virulence factors of this group of dimorphic fungi and the pathogenesis of emergomycosis. The virulence factor genes present in other members of the Ajellomycetaceae family are conserved in Es. pasteurianus and Es. africanus (8). The evolutionary transitions that this family of fungi has 
TABLE 1 | Current taxonomic classification and geographic distribution of Ajellomycetaceae family (order Onygenales) (2, 4, 5, 8-10).

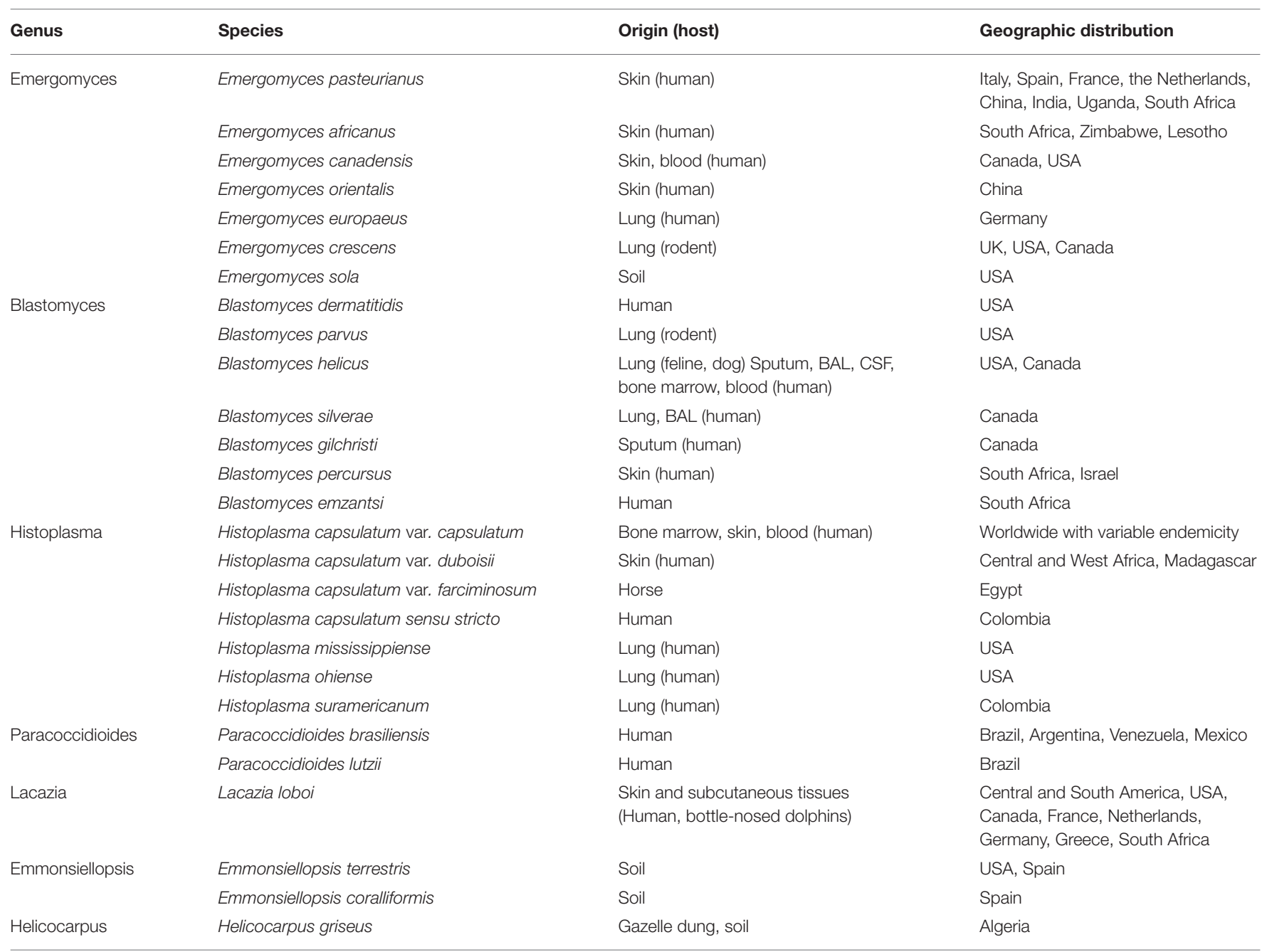

BAL, Bronchoalveolar lavage; CSF, Cerebrospinal fluid.

undergone, allow for their adaptation, infection and virulence in humans, and interactions with other eukaryotes in the environment that may help in maintaining their pathogenic potential in mammalian hosts. Besides, selection pressures in the environment are responsible for the emergence and maintenance of traits that confer upon them the capacity to survive in animal hosts. Munoz et al. (8) found significant expansions of the number of the fungal-specific protein kinase (FunK1) family, transcription factors and other genes associated with the regulation of gene expression in Ajellomycetaceae, highlighting their possible role in virulence and invasive disease. Es. pasteurianus, Es. africanus, and Es. europaeus (but not Es. canadensis and Es. orientalis) produce urease enzyme, a known virulence factor that impairs fungal clearance and leads to increased fungal burden at the primary site of infection (4, 30, 31). Lerm et al. (30) reported that the urease produced by Es. africanus is functionally similar to that of Cryptococcus neoformans, indicating its possible role in persistence of primary infection and subsequent extrapulmonary dissemination in susceptible hosts. Schwartz et al. (7) demonstrated that intraperitoneal inoculation of $\mathrm{BALB} / \mathrm{c}$ and $\mathrm{C} 57 \mathrm{BL} / 6$ mice with Es. africanus in doses of $10^{6}$ conidia resulted in significantly higher mortality in $\mathrm{C} 57 \mathrm{BL} / 6$ mice as compared with $\mathrm{BALB} / \mathrm{c}$ mice. This observation suggests that genetic background possibly has an influence on host susceptibility to the organism.

\section{CLINICAL PRESENTATION}

The primary route of infection is presumed to be inhalation of airborne conidia released from saprophytic mycelia in soil (7). Inside the human host, these conidia are transformed into yeast-like cells capable of replication and extrapulmonary dissemination. All reported cases of disseminated infection caused by Emergomyces spp. have occurred in immunocompromised adults, the vast majority of which had advanced HIV infection. Other underlying risk factors include neutropenia, solid organ transplantation, hematological malignancies, and use of immunosuppressive drugs (3). Earlier reports of the disease in immunocompetent patients from South 


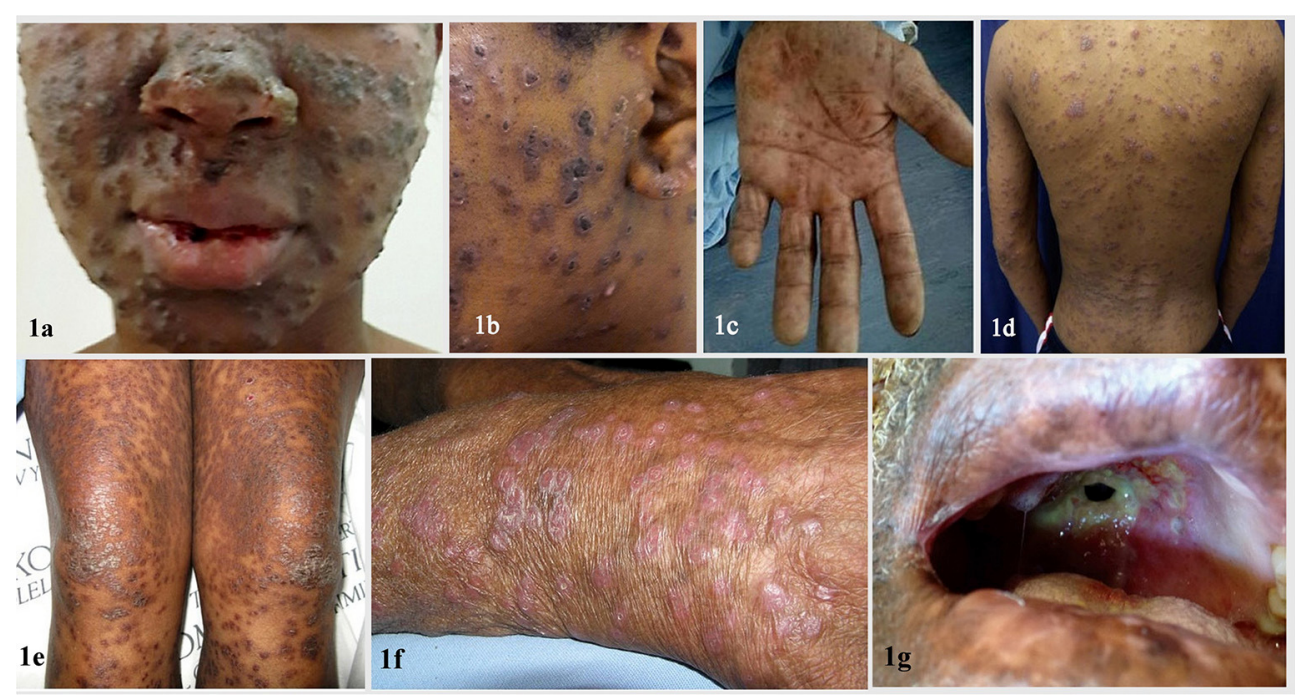

FIGURE 1 | Clinical images depicting various mucocutaneous manifestations of disseminated emergomycosis including ulcerated and crusted facial plaques and nodules (a,b), erythematous scaly lesions (c-f), palmar involvement (c), and oroantral fistula (g) Reproduced from references (27) (with permission) \& (32) (published under Creative Commons Attribution-Non-Commercial-NoDerivatives 4.0 International License).

Africa were, in fact, due to another novel dimorphic fungus endemic to the region, Blastomyces percursus (2). In a single case of the disease caused by Es. orientalis, there was no underlying immunodeficiency apart from type 2 diabetes mellitus (22). Emergomycosis is a multisystem disease with involvement of skin, lungs, liver, spleen, bone marrow, lymph nodes, brain, and cervix. Schwartz et al. (27) in a study from South Africa reported that $96 \%$ of patients with disseminated disease had cutaneous lesions; all of them had very low CD4+ T cell counts (median CD4 count 16 cells $/ \mathrm{mm}^{3}$ ) and were profoundly anemic. Cutaneous involvement occurs in the form of umbilicated papules, nodules, ulcers, verrucuous lesions, crusted plaques, and erythema $(27,32)$. Skin lesions with varying morphologies can be observed in individual patients (Figure 1).

Pulmonary involvement occurs in the form of diffuse and focal reticulonodular infiltrates, consolidations, lobar atelectasis, effusions, and hilar lymphadenopathy. Limited pulmonary disease has been observed in the sole reported case of the disease caused by Es. europaeus (23). The various clinical manifestations of disseminated emergomycosis are summarized in Table 2.

\section{DIFFERENTIAL DIAGNOSIS}

Emergomyces is a mimicking fungus and many initial cases were misdiagnosed as histoplasmosis, cryptococcosis, sporotrichosis, and blastomycosis (24). The cutaneous lesions of emergomycosis should be differentiated from varicella, scrofuloderma, papular eruption of HIV, cutaneous lesions of secondary syphilis, drug reactions, Kaposi sarcoma, guttate psoriasis, and pyoderma gangrenosum. Pulmonary lesions on chest radiograph may mimic pulmonary tuberculosis (27). Moreover, the morphological features of this fungus can be sometimes misleading. The yeast phase of Es. africanus
TABLE 2 | Clinical manifestations of emergomycosis (3, 21, 27, 32).

\begin{tabular}{ll}
\hline System involved & $\begin{array}{l}\text { Clinical manifestations, laboratory, and imaging } \\
\text { findings }\end{array}$
\end{tabular}

Skin Umbilicated papules, nodules, ulcers, verrucuous lesions, crusted hyperkeratotic plaques, erythema

Respiratory system Upper respiratory: epistaxis, nasal congestion, oroantral fistula

Lower respiratory: pneumonia, lobar atelectasis Imaging findings: diffuse and focal reticulonodular infiltrates, consolidations, lobar atelectasis, effusions, and hilar lymphadenopathy

Hematologic system Anemia, thrombocytopenia

Central nervous system Altered mental status, headache, seizure, ataxia, loss of visual acuity, personality changes Laboratory findings: CSF pleocytosis, low CSF glucose, elevated CSF protein

Gastrointestinal system Laboratory findings: elevated levels of serum bilirubin, alkaline phosphatise, alanine aminotransferase, aspartate aminotransferase, and gamma-glutamyl transferase Imaging findings: hepatomegaly, abnormal echogenicity of liver, splenic lesions, lymphadenopathy, abdominal mass

Genital system Endocervical mass

CSF, Cerebrospinal fluid.

closely resembles Histoplasma capsulatum, while that of Es. orientalis resembles Blastomyces dermatitidis (4). Histopathology can detect yeasts, but is unable to differentiate between the different fungal genera. Therefore, fungal culture is imperative for differentiating between these dimorphic fungi. However, the mold phase of Es. africanus closely resembles Sporothrix schenckii on microscopy (32). For all these reasons, molecular 
techniques like sequencing are considered as the reference tool for identification.

\section{DIAGNOSIS}

Diagnosis of emergomycosis poses a challenge for the clinicians and microbiologists. Studies indicate that three-quarters of patients with emergomycosis get misdiagnosed as tuberculosis and receive treatment for the latter (27). Diagnosis can be made by histopathological examination and fungal culture of affected tissue obtained by biopsy. The recent introduction of molecular techniques has improved the diagnostic accuracy. Blood, skin tissue, bone marrow aspirate and/or trephine biopsy, lymph node aspirate, induced sputum, or bronchoalveolar lavage (BAL) specimens are appropriate for mycological investigations.

\section{Histopathology}

There is considerable overlap between the histopathological features of emergomycosis and histoplasmosis. In fact, these infections are virtually indistinguishable from one another on histopathology, and a definitive diagnosis therefore, requires detailed clinicopathological correlation and the use of fungal culture and molecular identification techniques (33). Hematoxylin-eosin, periodic acid-Schiff, and Gomori's methenamine silver stains can be used to demonstrate the intracellular yeasts with surrounding inflammatory changes in the affected tissue. Histology of skin biopsy specimen shows chronic granulomatous and/or suppurative dermal infiltrates containing histiocytes, multinucleated giant cells, and plasma cells, together with intracytoplasmic narrowbased budding yeasts, measuring $2-5 \mu \mathrm{m}$ in size $(24,32)$. Sometimes pseudo-epitheliomatous hyperplasia accompanied by transepidermal and/or transfollicular elimination of the fungal organisms can also be seen. There may be invasion of the dermal nerves. In profoundly immunosuppressed individuals, the host inflammatory response may be minimal to virtually absent, and in such cases, the skin biopsy may appear nearnormal (32). Cases occurring as a manifestation of immune reconstitution inflammatory syndrome (IRIS) exhibit a more pronounced mixed dermal inflammatory infiltrate and even microabscess formation (34).

\section{Fungal Culture}

Emergomyces spp. grow readily on routine mycology media like Sabouraud dextrose agar (SDA), malt extract agar (MEA), or potato dextrose agar (PDA), incubated at $24-30^{\circ} \mathrm{C}$. Colonies are yellowish white to tan, initially glabrous, becoming powdery, slightly raised and furrowed, and reach diameters of $2.5-3.5 \mathrm{~cm}$ in 2 weeks (Figure 2a). Reverse is ochraceous-buff to warmbuff peripherally (Figure 2b). Microscopic morphology of the mold phase in lactophenol cotton blue preparation exhibits slender conidiophores arising at right angles from thin-walled
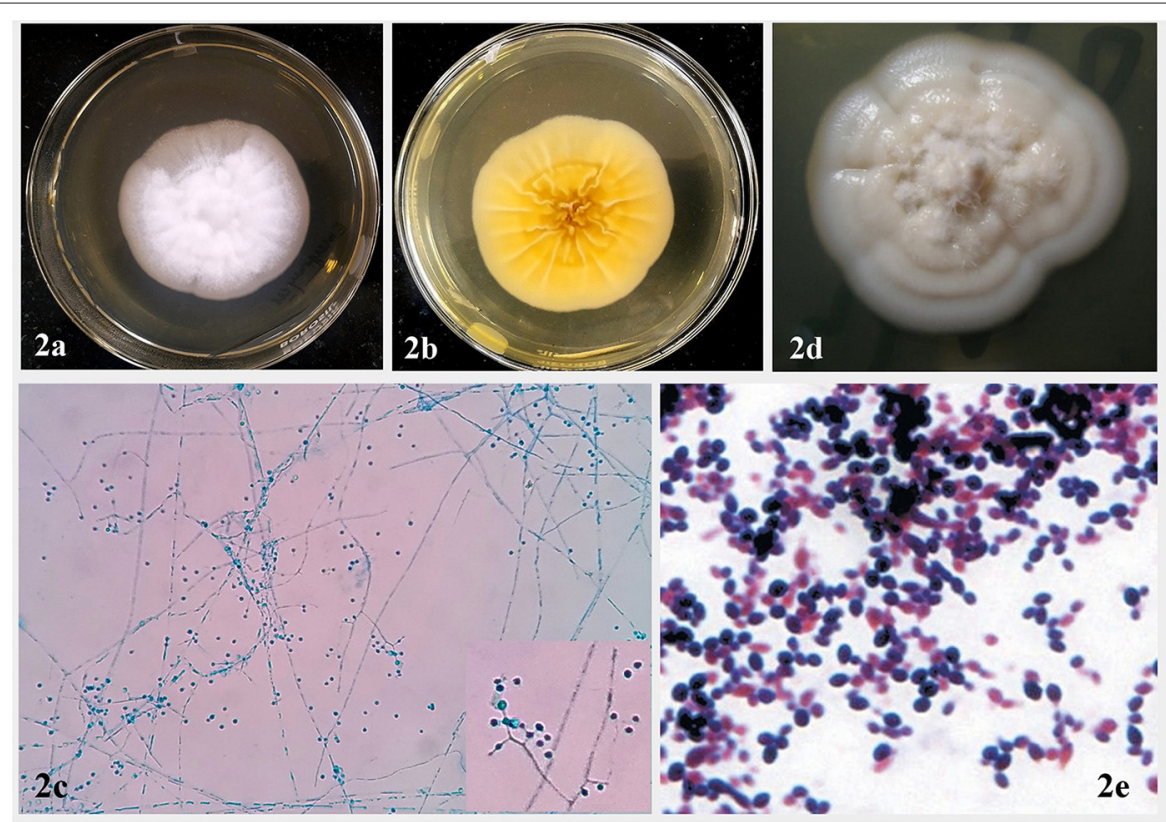

FIGURE 2 | Colony characteristics and microscopic morphology of mycelial phase of Emergomyces spp. on SDA after 14 days of incubation at $25^{\circ} \mathrm{C}$. (a) Obverse showing white to tan, initially glabrous colony, which becomes powdery, slightly raised, and furrowed with age. (b) Reverse showing ochraceous-buff to warm buff peripherally. (c) Microscopic morphology in lactophenol cotton blue preparation showing "florets" of smooth-walled subglobose conidia borne on slender conidiophores, slightly swollen at the tip and arising at right angles from thin-walled hyaline hyphae (inset) (Courtesy: Advanced Mycology Laboratory, Department of Microbiology, All India Institute of Medical Sciences, Jodhpur, Rajasthan, India). (d) Yeast phase of Emergomyces species on BHI agar, showing yeast-like, pasty, cerebriform yellowish-white to tan colonies after $2-3$ weeks of incubation at $37^{\circ} \mathrm{C}$. (e) Gram stain morphology of yeast phase showing Gram positive round to oval yeast cells with narrow based budding (Reproduced from references (20) and (22), published under Creative Commons Attribution-Non-Commercial-NoDerivatives 4.0 International License). 
TABLE 3 | Morphological features of yeast and mold phases of Emergomyces species (4).

\begin{tabular}{|c|c|c|c|c|c|}
\hline Species & \multicolumn{2}{|c|}{ Saprobic phase $\left(24^{\circ} \mathrm{C}\right)$} & \multicolumn{2}{|c|}{ Thermotolerant phase $\left(37^{\circ} \mathrm{C}\right)$} & Comments \\
\hline $\begin{array}{l}\text { Emergomyces } \\
\text { pasteurianus }\end{array}$ & $\begin{array}{l}\text { Obverse-Yellowish white, } \\
\text { dense, felty to floccose, } \\
\text { radially sulcate. } \\
\text { Reverse-Ochraceous-buff to } \\
\text { warm buff peripherally. }\end{array}$ & $\begin{array}{l}\text { Conidiophores with } \\
\text { septa at the base and } \\
\text { at conidial insertion, } \\
\text { cylindrical, or } \\
\text { moderately swollen at } \\
\text { the tip. Conidia formed } \\
\text { singly or in short chains } \\
(2-4), \text { subspherical, } \\
0.9-2.8 \times 1.8-3.2 \mu \mathrm{m} \text {, } \\
\text { smooth to finely } \\
\text { roughened. Some } \\
\text { chlamydospore-like } \\
\text { cells arise terminally on } \\
\text { short lateral branches, } \\
\text { with thickened walls } \\
\text { and often with a } \\
\text { median septum }\end{array}$ & $\begin{array}{l}8 \mathrm{~mm} \text { diameter, } \\
\text { yeast-like, cerebriform, } \\
\text { yellowish-white. }\end{array}$ & $\begin{array}{l}\text { Hyphae scant, } \\
\text { moniliform, some cells } \\
\text { becoming giant cells, } \\
5.4-12 \mu \mathrm{m} \text { wide. Yeast } \\
\text { cells arise from giant } \\
\text { cells or from fragments } \\
\text { of swollen } \\
\text { conidiophores or } \\
\text { hyphae; small yeasts } \\
\text { with narrow-based } \\
\text { budding, } 2.1-5.1 \times \\
1.6-4.2 \mu \mathrm{m} \text {; larger } \\
\text { yeasts } 5.0-11.2 \times \\
2.4-6.3 \mu \mathrm{m} \text {, with uni- } \\
\text { or bipolar budding from } \\
\text { narrow or broad bases. }\end{array}$ & $\begin{array}{l}\text { Conversion to yeast is } \\
\text { slower ( } 2-3 \text { weeks) and } \\
\text { occurs at higher } \\
\text { temperature }\left(37^{\circ} \mathrm{C}\right) \\
\text { than in Es. africanus } \\
\text { and Es. europaeus. }\end{array}$ \\
\hline $\begin{array}{l}\text { Emergomyces } \\
\text { africanus }\end{array}$ & $\begin{array}{l}\text { Obverse-Yellowish-white, } \\
\text { glabrous to floccose centrally, } \\
\text { radially sulcate. } \\
\text { Reverse-Warm-buff to light } \\
\text { buff peripherally. }\end{array}$ & $\begin{array}{l}\text { Conidiophores with a } \\
\text { septum at the base and } \\
\text { at conidial insertion; } \\
\text { moderately swollen at } \\
\text { the tip with } 4-8 \text { conidia } \\
\text { borne on narrow } \\
\text { pedicels. Conidia single } \\
\text { or in short chains ( } 2-4) \text {, } \\
\text { subspherical, } 1.2-3.2 \\
\times 1.7-3.8 \mu \mathrm{m}, \text { smooth } \\
\text { to finely roughened. }\end{array}$ & $\begin{array}{l}7 \mathrm{~mm} \text { diameter, } \\
\text { yeast-like, cerebriform, } \\
\text { yellowish-white. }\end{array}$ & $\begin{array}{l}\text { Hyphae scant. Yeast } \\
\text { cells abundant, ovoidal } \\
\text { to subspherical, } \\
1.7-5.3 \times 0.9-2.2 \mu \mathrm{m} \\
\text { with unipolar budding } \\
\text { at a narrow base. }\end{array}$ & $\begin{array}{l}\text { Development of } \\
\text { secondary } \\
\text { conidiophores leading } \\
\text { to a complex cluster of } \\
4-8 \text { conidia and } \\
\text { production of } \\
\text { small-celled yeasts at } \\
37^{\circ} \mathrm{C} \text { within } 1 \text { week. }\end{array}$ \\
\hline $\begin{array}{l}\text { Emergomyces } \\
\text { orientalis }\end{array}$ & $\begin{array}{l}\text { Obverse-Yellowish white, felty } \\
\text { with hyphal tufts centrally, radially } \\
\text { sulcate. } \\
\text { Reverse-Ochraceous-buff to } \\
\text { warm-buff peripherally. }\end{array}$ & $\begin{array}{l}\text { Conidiophores } \\
\text { cylindrical or slightly } \\
\text { swollen in the middle, } \\
\text { with a septum at the } \\
\text { base, thin secondary } \\
\text { conidiophores present. } \\
\text { Conidia subspherical, } \\
1.1-2.8 \times 1.7-4.8 \mu \mathrm{m} \\
\text { smooth to slightly } \\
\text { roughened. }\end{array}$ & $\begin{array}{l}5 \mathrm{~mm} \text { diameter, } \\
\text { yeast-like, cerebriform, } \\
\text { yellowish white. }\end{array}$ & $\begin{array}{l}\text { Hyphal elements scant. } \\
\text { Yeast cells spherical, } \\
2.0-4.5 \mu \mathrm{m} \text { diam, with } \\
\text { uni- or bipolar budding } \\
\text { at a narrow base. Few } \\
\text { giant cells present. }\end{array}$ & $\begin{array}{l}\text { Produces conidia at } \\
21^{\circ} \mathrm{C} \text { but not at } 24^{\circ} \mathrm{C} \text {. } \\
\text { Urease test is negative, } \\
\text { red pigment produced } \\
\text { on } \mathrm{BHI} A \text { and TSA at } \\
37^{\circ} \mathrm{C} \text {. Time for } \\
\text { transformation to yeast } \\
\text { at } 37^{\circ} \mathrm{C} \text { is slow (2 } \\
\text { weeks). }\end{array}$ \\
\hline $\begin{array}{l}\text { Emergomyces } \\
\text { europaeus }\end{array}$ & $\begin{array}{l}\text { Obverse- Dense, white, felty to } \\
\text { floccose, radially sulcate, } \\
\text { glabrous at the margin. } \\
\text { Reverse-Warm-buff to light } \\
\text { buff periphally. }\end{array}$ & $\begin{array}{l}\text { Conidiophores } \\
\text { unbranched, with } \\
\text { septum at the base, } \\
\text { cylindrical to slightly } \\
\text { swollen at the tip, } \\
\text { bearing one or two } \\
\text { subspherical, slightly } \\
\text { roughened conidia, } \\
\text { measuring 2.9-5.7 } \\
\text { 3.0-5.7 um }\end{array}$ & $\begin{array}{l}4 \mathrm{~mm} \text { diameter, } \\
\text { yeast-like, pasty, } \\
\text { cerebriform, tan }\end{array}$ & $\begin{array}{l}\text { Swollen hyphae and } \\
\text { giant cells present; } \\
\text { yeast cells ovoidal to } \\
\text { subspherical, } 2.6-5.9 \\
\times 17-3.8 \mu \mathrm{m} \text { with uni- } \\
\text { or bipolar budding at a } \\
\text { narrow base. }\end{array}$ & $\begin{array}{l}\text { Es. europaeus has } \\
\text { conidiophores without } \\
\text { secondary branches } \\
\text { and conidia are larger } \\
\text { and more roughened } \\
\text { than those of other } \\
\text { species. Yeast } \\
\text { transformation occurs } \\
\text { at a lower temperature } \\
\left(33^{\circ} \mathrm{C}\right) \text {. }\end{array}$ \\
\hline
\end{tabular}


hyaline hyphae, slightly swollen at the tip, sometimes with short secondary conidiophores bearing "florets" of solitary singlecelled subspherical conidia (Figure 2c). For conversion from mold to the yeast phase, mold colony from SDA is subcultured on MEA or brain heart infusion (BHI) agar containing 5\% sheep blood and incubated at $35^{\circ} \mathrm{C}$. Yellowish-white to tan, pasty, cerebriform colonies appear after 2-3 weeks of incubation (Figure 2d). Gram stained smear prepared from culture reveals small, oval yeast cells with narrow based budding (Figure 2e). The morphological features of mycelial and yeast phases of Emergomyces species have been summarized in Table 3.

\section{Molecular Identification}

Mycologists have traditionally used morphological (phenotypic) characteristics, such as conidiogenesis for fungal identification. It is still being used routinely for classification of fungi at the ordinal or family level in most mycology laboratories. However, morphological features may considerably overlap between different fungal genera and therefore, may not be ideal for speciation. For example, the mycelial form of Emergomyces spp. sometimes resembles Sporothrix schenckii, another dimorphic fungus causing subcutaneous mycosis in endemic regions (32). Therefore, molecular techniques like polymerase chain reaction (PCR) and sequencing are considered as the gold standard for identification. They can also be employed for direct detection of fungi in clinical and environmental samples. However, the diagnostic accuracy of molecular assays depends on several factors, such as optimal specimen selection, fungal load in specimens, and primer design (pan-fungal or speciesspecific). It is crucial to differentiate environmental fungal DNA contamination from target fungal DNA in clinical specimens, particularly while using pan-fungal primers (35). At present, there are no commercially available molecular diagnostic tests for Emergomyces spp. Recently, Alanio et al. (36) demonstrated excellent sensitivity of a whole nucleic acid-based reverse transcriptase quantitative PCR (RTqPCR) assay for the diagnosis of histoplasmosis and the same platform is being evaluated for emergomycosis.

\section{From Culture Isolate}

Fungal genomic DNA is extracted from a 20-day-old culture of the isolate using commercially available kits like Zymo ZR fungal/bacterial DNA MiniPrep kit (Zymo Research, Irvine, CA) or MasterPure ${ }^{\mathrm{TM}}$ Yeast DNA Purification Kit (Epicentre, Madison, WI, U.S.A.), followed by PCR and sequencing of the ITS and LSU regions of the ribosomal DNA with primer pairs ITS5 (5'-GGAAGTAAAAGTCGTAACAAGG-3') and ITS4 (5'TCCTCCGCTTATTGATATGC- $\left.3^{\prime}\right)$, and LROR (5' -ACCCGCTG AACTTAAGC- $\left.3^{\prime}\right)$ and LR5 (5'-TCCTGAGGGAAACTTCG-3'), respectively $(2,37)$. Candida albicans ATCC 90028 is included as a quality control (QC) strain during PCR and sequencing of the ITS region.

\section{From Tissue Specimen}

When fungal cultures are negative or omitted, PCR of fresh, affected tissue specimen with amplification and sequencing of the ITS and LSU regions can help in establishing the correct diagnosis. The tissue samples are first homogenized in lysis buffer (containing $\beta$-mercaptoethanol) with either a homogeniser or by repeatedly passing the finely chopped tissue specimen through a 2-ml syringe with a 22-gauge needle. Samples are then centrifuged and the cell-free supernatant is used as starting material as per the manufacturer's instructions. The extracted DNA concentration is determined spectrophotometrically and a conventional PCR is used to screen samples for the presence of fungal DNA (29). The universal fungal locus ITS1-5.8S-ITS2 and partial LSU region of rDNA are amplified using primer pairs ITS5 and ITS4, and LROR and LR5, respectively, operated under standard PCR conditions as described by Dukik et al. (2) Sequences are determined by capillary electrophoresis and identification to the species level is done with the National Center for Biotechnology Information (NCBI) Basic Local Alignment Search Tool (BLAST) database on the basis of pairwise sequence alignment. It should be noted that Emergomyces spp. can crossreact with a commercial $B$. dermatitidis DNA probe (AccuProbe, Hologic, Inc., San Diego, CA, USA) (21).

\section{From Formalin-Fixed, Paraffin-Embedded (FFPE) Tissue}

Identification of fungi from histopathology sections is limited by failure of species identification. In such cases, fungal DNA can be extracted from FFPE tissue biopsy sections and amplified by PCR targeting ITS region of the fungal ribosomal RNA genes. Rooms et al. (38) diagnosed a case of disseminated emergomycosis caused by Es. pasteurianus in Uganda by using two broad-range fungal PCR assays targeting a region of the $28 S$ and the ITS2 region, which was confirmed by phylogenetic analysis. While ITS2 targets a diverse, non-coding region (200$300 \mathrm{bp}$ ) well represented in public databases, $28 \mathrm{~S}$ targets a more conserved coding region (330-350 bp), ideal for identification to genus level but not suitable for species resolution and is underrepresented in public databases $(2,39)$. Studies have shown that broad-range fungal PCR with sequencing is more successful in identifying fungal pathogens in pathology blocks, with even better performance by enhancing DNA recovery from tissue. However, amplification of fungal DNA from FFPE tissue is restricted by amplicon length, PCR inhibition, an excess of host DNA, and contaminating fungal DNA $(39,40)$.

\section{Serodiagnosis}

There are no sensitive and specific serological tests or biomarkers for the diagnosis of emergomycosis. However, cross-reactivity has been observed with tests for other dimorphic fungal pathogens. Schwartz et al. (27) in a retrospective case series reported that two out of three patients of emergomycosis had positive urine Histoplasma galactomannan antigen and one out of four cases had positive 1,3- $\beta$-D-glucan test. A recent study by Maphanga et al. (41) also demonstrated cross-reactivity of Histoplasma galactomannan enzyme immunoassay in urine specimens of patients with Es. africanus. Further studies are required to evaluate the diagnostic and prognostic significance of various serological markers in emergomycosis. 


\section{ANTIFUNGAL SUSCEPTIBILITY TESTING}

The Clinical and Laboratory Standards Institute (CLSI) and the European Committee on Antimicrobial Susceptibility Testing (EUCAST) have established reference methods for susceptibility testing of yeasts (M27-A3) and molds (M38-A2) to the major classes of antifungal drugs which include the polyenes, azoles, and echinocandins. However, these reference methods have not been extended to include the dimorphic fungi leading to confusion as to whether susceptibility testing methods for yeasts or for molds should be followed (42). This issue is critical as the yeast and hyphal forms of dimorphic fungi exhibit different susceptibility patterns. Unfortunately, most antifungal studies continue to ignore the pathogenic yeast phase and instead, limit observation to mycelial-phase cells. Although conversion from mold to yeast phase increases the turnaround time, laboratory safety concerns are fewer with the yeast phase compared to the potentially hazardous mold phase. Hence, susceptibility testing with the yeast phase is recommended (37). There are no well-standardized methods for MIC determination of thermally dimorphic fungi. Antifungal susceptibility testing can be performed on yeast and mold phase isolates of Emergomyces spp. by a reference broth microdilution (BMD) method and the commercial Epsilometer test (E-test) method, as described by Maphanga et al. (37) The method follows the CLSI-approved standards for testing yeast and mycelial phases, but uses a larger-than-recommended inoculum for the latter $\left(2.5 \times 10^{5} \mathrm{CFU} / \mathrm{ml}\right.$, diluted 1:10 in Roswell Park Memorial Institute [RPMI] 1640 medium) and a prolonged incubation period of 7 days to facilitate growth and endpoint determinations $(14,39,43)$.

\section{TREATMENT}

Currently, there are four classes of antifungal drugs for the treatment of systemic mycoses: polyenes (amphotericin B), azoles (fluconazole, itraconazole, posaconazole, voriconazole, and isavuconazole), echinocandins (caspofungin, micafungin and anidulafungin), and antimetabolites (flucytosine). To date, there are no treatment guidelines for patients with emergomycosis. In absence of randomized controlled trials, it is recommended that treatment of disseminated emergomycosis should follow the Infectious Diseases Society of America guidelines for the management of endemic mycoses in immunocompromised persons (44).

In general, the dimorphic fungal pathogens exhibit a similar susceptibility profile for current antifungals with both amphotericin B and azoles (except fluconazole) showing potent activity (low minimum inhibitory concentrations; MIC) (42). The recommended regimen consists of amphotericin B (deoxycholate formulation $0.7-1.0 \mathrm{mg} / \mathrm{kg}$ daily or preferably, a liposomal formulation 3-5 mg/kg daily) for 1-2 weeks, followed by oral itraconazole $(200 \mathrm{mg}$ three times daily for 3 days and then $200 \mathrm{mg}$ twice daily) for at least 12 months. Lifelong suppressive therapy with itraconazole ( $200 \mathrm{mg}$ daily) may be required if immunosuppression cannot be reversed (44). The efficacy of different classes of antifungal drugs in the treatment emergomycosis are described below.

\section{Polyenes}

Polyenes exert fungicidal activity by binding to ergosterol in the fungal cell membrane, resulting in its disintegration and the leakage of intracellular components, which subsequently leads to cell death (45). Amphotericin B has a broad spectrum of fungicidal activity and is recommended for the treatment of severe disseminated emergomycosis (3). Dukik et al. (42). evaluated the susceptibility patterns of 24 isolates from three clinically related genera, Emergomyces, Adiaspiromyces, and Blastomyces and reported that amphotericin B was the most active antifungal agent having the lowest MICs against all species, with geometric mean (GM) MIC and MIC ranges for Emergomyces being 0.049 and $<0.016-0.25 \mu \mathrm{g} / \mathrm{mL}$, respectively. Maphanga et al. (37) studied the MIC distribution of yeast and mold phases of 50 Es. africanus isolates and observed a low GM MIC of amphotericin B (Etest MICs 0.03 vs. 0.01 $\mathrm{mg} / \mathrm{L}$ ). Also, patients who received an antifungal regimen that included amphotericin B had a higher survival rate and better clinical outcome than those treated with a triazole alone. Similar findings were reported by Schwartz et al. (27) These observations highlight amphotericin B as the cornerstone in the management of disseminated emergomycosis.

\section{Azoles}

Azoles act by inhibiting lanosterol $14 \alpha$-demethylase, a key enzyme in ergosterol biosynthesis, resulting in depletion of ergosterol and accumulation of toxic $14 \alpha$-methylated sterols in membranes $(46,47)$. Several studies have documented high MIC for fluconazole and therefore, less potent as compared to other azoles in the treatment of emergomycosis $(17,31,37,42)$. Schwartz et al. (27) observed that therapy with fluconazole was associated with increased mortality and poor outcomes. Interestingly, Moodley et al. (24) reported successful treatment of a case of disseminated emergomycosis caused by Es. africanus with 6 months of fluconazole monotherapy, as evidenced by complete resolution of skin lesions and clinical improvement. Among the newer triazoles, low MIC has been observed for itraconazole which makes it ideal for oral step-down phase following amphotericin B therapy $(37,42)$. However, due to nonlinear pharmacokinetics, high intra-subject variability in plasma concentrations and risk of drug-drug interactions, therapeutic drug monitoring is mandatory in such patients (45-48). Dukik et al. (42) studied the in vitro susceptibility patterns of 11 isolates of Emergomyces spp. and reported that posaconazole had the lowest GM MIC values, followed by amphotericin B, itraconazole, voriconazole, and isavuconazole. A susceptibility study on yeast and mold phases of 50 Es. africanus isolates, also demonstrated low GM MIC value for posaconazole (37). Furthermore, a case of disseminated infection caused by Es. pasteurianus in Netherlands was successfully treated with 14 months of posaconazole therapy (18), indicating that posaconazole can be a possible treatment option for patients with disseminated disease. Isavuconazole is a novel triazole that has shown promise in the treatment of endemic mycoses in animal models (49, 50). However, studies have reported comparatively high MIC values against Emergomyces spp. $(18,42)$ and therefore, cannot be considered as a suitable treatment option in such cases. 
Although itraconazole is commonly recommended for long-term treatment of endemic mycoses in HIV infected patients, caution should be exercised during concurrent administration with antiretroviral drugs, particularly protease inhibitors (PIs) and non-nucleoside reverse transcriptase inhibitors (NNRTIs) (51). Itraconazole being a substrate of CYP450 3A4 isoenzyme, PIs like lopinavir/ritonavir increase the serum levels of itraconazole resulting in toxicity (manifested by QT prolongation), while NNRTIs like nevirapine and efavirenz decrease its serum concentrations, leading to therapeutic failure. These potential drug-drug interactions limit their co-administration. However, integrase inhibitors like dolutegravir and raltegravir, which are currently recommended for the treatment of HIV infection are free from such adverse interactions and therefore, can be administered concurrently with itraconazole (52). In addition, the bioavailability of oral itraconazole is affected by gastric $\mathrm{pH}$ - bioavailability is enhanced when taken with food but reduced by $40 \%$ in the fasting state. AIDS-related hypochlorhydria also decreases its absorption significantly (53).

\section{Echinocandins}

The echinocandins (caspofungin, anidulafungin, micafungin) inhibit the fungal 1,3- $\beta$-D-glucan synthase and depletes the fungal cell wall of $1,3-\beta$-D-glucan, causing lysis of the fungal cell. However, they lack efficacy against the pathogenic phase of dimorphic fungal pathogens, including Emergomyces spp. (43) Maphanga et al. (37) studied the antifungal susceptibility pattern in 50 clinical isolates of Es. africanus and observed high GM MIC values for all three echinocandins tested. Similar results were obtained by Dukik et al. (42) for anidulafungin and micafungin.

\section{PROGNOSIS}

Disseminated emergomycosis is fatal if left untreated and patients who receive an antifungal regimen that includes amphotericin $\mathrm{B}$ are more likely to survive than those treated with a triazole alone. Monotherapy with either fluconazole or itraconazole are associated with poor outcomes. Schwartz et al. (27) in a retrospective case series of 54 patients with disseminated emergomycosis observed a case fatality rate of $48 \%$, which included, among others, all of the patients that did not receive antifungal treatment.

\section{FUTURE PROSPECTS: WHAT IS THERE IN THE PIPELINE?}

Considering the host toxicity profile of currently available antifungal drugs and the endogenous resistance of dimorphic fungi to the less toxic echinocandins, new and alternative antifungal drugs, preferably with novel modes of action (to avoid cross-resistance and/or cross-toxicities) need to be explored. Also, the availability of oral formulations would enable ambulatory treatment resulting in improved patient compliance and adherence to treatment. So far, none of the new antifungal agents have been evaluated for the treatment of emergomycosis. Some of the attractive antifungal candidates that might hold promise in the treatment of emergomycosis are summarized in Table 4.

\section{Amphotericin B Cochleate}

Amphotericin B cochleate (CAMB/MAT2203; Matinas BioPharma) is a new oral formulation belonging to the polyene class which is currently under Phase II clinical trial. Unlike other formulations, the cochleate form is stable against degradation in the gastrointestinal tract. Cochleate consists of a spiral structure made up of phosphatidylserine with phospholipid-calcium precipitates (54). Following oral administration, the cochleate is absorbed from the GI tract and enters circulation where the calcium moiety is removed and the spiral formation opens up and releases the encapsulated drug into the target cell. The limitations of cochleate formulations include high cost, stringent storage conditions $\left(4^{\circ} \mathrm{C}\right)$, and precipitation during storage (55).

\section{SUBA-Itraconazole}

The bioavailability of conventional oral itraconazole is limited by elevated gastric $\mathrm{pH}$ due to AIDS related hypochlorhydria, and use of proton pump inhibitors and $\mathrm{H}_{2}$ blockers. In order to improve the oral bioavailability, the drug has been optimized as super-bioavailability-itraconazole (SUBA-itraconazole; Mayne Pharmaceuticals), which is not affected by food or gastric $\mathrm{pH}$ (56). This new formulation utilizes the solid dispersion of the drug in a $\mathrm{pH}$-dependent polymer matrix to enhance dissolution and absorption, thereby increasing oral bioavailability (173\%) while reducing inter-patient variability (57). SUBAitraconazole has been approved by the FDA for the treatment of blastomycosis, histoplasmosis, and aspergillosis (in patients intolerant or refractory to amphotericin B therapy). It is currently available as a $65 \mathrm{mg}$ oral capsule, with a potential loading dose of $130 \mathrm{mg}$ three times daily for the first 3 days, followed by a maintenance dose of $130 \mathrm{mg}$ once daily.

\section{Olorofim (F901318)}

Olorofim (F901318; F2G Ltd.), belonging to the class of orotomides, is a new antifungal drug under Phase III clinical trial that acts by inhibiting dihydroorotate dehydrogenase (58), a key enzyme in pyrimidine biosynthesis, which adversely affects fungal nucleic acid, cell wall and phospholipid synthesis, cell regulation and protein production (59). Olorofim has a good bioavailability and can be administered both orally and intravenously. It is widely distributed in tissues, such as kidney, liver, lung, and even brain (58). Besides its activity against Scedosporium, Lomentospora, and various cryptic species of Aspergillus $(47,60)$, it has been found to be effective against Coccidioides and other endemic fungi (61). The novel mechanism of action, broad spectrum of antifungal activity and absence of cross-resistance with other antifungal classes make Olorofim a promising candidate for the treatment of emergomycosis.

\section{Fosmanogepix (APX001)}

Fosmanogepix (FMGX, APX001, Amplyx Pharmaceuticals) is a prodrug of manogepix that inhibits fungal enzyme 
TABLE 4 | Antifungal drugs with novel targets in development and their spectrum of activity.

\begin{tabular}{|c|c|c|c|c|c|}
\hline Drug class & Antifungal agent & Mechanism of action & Target species & $\begin{array}{l}\text { Trial phase and } \\
\text { manufacturer }\end{array}$ & Advantages \\
\hline Polyene & $\begin{array}{l}\text { Amphotericin B } \\
\text { cochleate }\end{array}$ & $\begin{array}{l}\text { Cochleate consists of a } \\
\text { spiral structure made up of } \\
\text { phosphatidylserine with } \\
\text { phospholipid-calcium } \\
\text { precipitates. It is stable } \\
\text { against degradation by } \\
\text { gastric acid, gets readily } \\
\text { absorbed from Gl tract and } \\
\text { enters circulation where the } \\
\text { calcium moiety is removed } \\
\text { and the spiral formation } \\
\text { opens up and releases the } \\
\text { encapsulated drug into the } \\
\text { target cell. }\end{array}$ & $\begin{array}{l}\text { Candida, Aspergillus, } \\
\text { Cryptococcus }\end{array}$ & $\begin{array}{l}\text { Phase II } \\
\text { Matinas BioPharma }\end{array}$ & $\begin{array}{l}\text { Oral formulation, less } \\
\text { toxic, minimal } \\
\text { drug-drug interactions }\end{array}$ \\
\hline Orotomides & Olorofim & $\begin{array}{l}\text { Inhibition of fungal } \\
\text { dihydroorotate } \\
\text { dehydrogenase and } \\
\text { pyrimidine synthesis }\end{array}$ & $\begin{array}{l}\text { Aspergillus, } \\
\text { Histoplasma, } \\
\text { Blastomyces, } \\
\text { Coccidioides, } \\
\text { Talaromyces marneffei, } \\
\text { Lomentospora }\end{array}$ & $\begin{array}{l}\text { Phase II } \\
\text { F2G Ltd. }\end{array}$ & $\begin{array}{l}\text { Oral formulation, less } \\
\text { toxic (fungal specific), } \\
\text { active against multidrug } \\
\text { resistant fungi }\end{array}$ \\
\hline Phosphonooxymethylene & Fosmanogepix & $\begin{array}{l}\text { Inhibition of fungal Gwt1 } \\
\text { GPI anchor protein }\end{array}$ & $\begin{array}{l}\text { Candida (except C. } \\
\text { krusei), Aspergillus, } \\
\text { Fusarium, } \\
\text { Scedosporium, } \\
\text { Coccidioides, some } \\
\text { mucorales }\end{array}$ & $\begin{array}{l}\text { Phase II } \\
\text { Amplyx Pharmaceuticals }\end{array}$ & $\begin{array}{l}\text { Oral formulation, less } \\
\text { toxic (fungal specific), } \\
\text { broad spectrum } \\
\text { antifungal activity }\end{array}$ \\
\hline Celecoxib derivative & AR-12 & $\begin{array}{l}\text { Inhibition of fungal } \\
\text { acetyl-CoA synthetase }\end{array}$ & $\begin{array}{l}\text { Candida, } \\
\text { Cryptococcus, } \\
\text { Blastomyces, } \\
\text { Histoplasma, } \\
\text { Coccidioides, } \\
\text { Fusarium, Mucor, } \\
\text { Lomentospora }\end{array}$ & $\begin{array}{l}\text { Phase I (oncology } \\
\text { indications) } \\
\text { Arno Therapeutics }\end{array}$ & $\begin{array}{l}\text { Repurposed drug with } \\
\text { potent broad-spectrum } \\
\text { antifungal activity }\end{array}$ \\
\hline
\end{tabular}

Gl, Gastrointestinal; CYP, Cytochrome P; GPI, Glycosylphospatidyl inositol; acetyl-CoA, acetyl coenzyme A.

Gwt1 and affects maturation and localization of GPIanchored mannoproteins, leading to alterations of cell wall integrity, adhesion, and host immune evasion. The drug has excellent bioavailability following oral and intravenous administrations and is currently under Phase 2 clinical trials for the treatment of invasive fungal infections caused by Candida, Aspergillus, Fusarium, Scedosporium, and some mucorales (62). It has also demonstrated significant activity against Coccidioides spp. in murine model as evident by decreased fungal burden, halting systemic disease, and longer survival of FMGX-treated mice (63). Thus, considering its unique mechanism of action and broad spectrum antifungal activity, fosmanogepix is worthy of further evaluation for the treatment of emergomycosis.

\section{Nikkomycin Z (VFS-1)}

Nikkomycin Z (Valley Fever Solutions, Inc.) is a modifiednuceloside analog belonging to the class of polyoxins. It is a 
competitive inhibitor of chitin synthase that blocks fungal cell wall synthesis. It exhibits synergistic activity with the $1,3-\beta-D-$ glucan synthase inhibitors like echinocandins (47). Nikkomycin $\mathrm{Z}$ is currently in Phase I clinical trial and in vitro studies have demonstrated good efficacy against dimorphic fungal pathogens, such as Histoplasma capsulatum (64), Blastomyces dermatitidis, Coccidioides immitis (65), and Sporothrix spp. (66) Its action against Emergomyces spp. needs to be evaluated.

\section{Tetrazole (VT-1598)}

Tetrazole antifungals are novel azole-like compounds that inhibit fungal lanosterol demethylase, resulting in decreased ergosterol synthesis and inhibiting cell membrane formation. Unlike currently available triazoles that interact with human CYP450 enzymes, tetrazoles exhibit high degree of selectivity for fungal CYP51 and consequently fewer drug-drug interactions (67). VT-1598 (Mycovia Pharmaceuticals) is currently in Phase II clinical trial and demonstrates activity against yeasts, molds, and endemic fungi (B. dermatitidis, Coccidioides spp., and $H$. capsulatum). Low MIC values and improved survival have been observed with VT-1598 against Coccidioides spp. in a murine model (68). Considering its broad-spectrum of activity against dimorphic fungi and favorable safety profile, VT-1598 might be a potential treatment option for emergomycosis.

\section{AR-12}

AR-12 (Arno Therapeutics), a celecoxib derivative, was originally developed as an anticancer drug and is currently under phase I trial. Its antifungal activity is attributed to inhibition of fungal acetyl-CoA synthetase, causing depletion of acetyl coenzyme A (acetyl-CoA). It also downregulates host chaperone proteins and augments host immune response (46). The drug has demonstrated promising in vitro activity against Candida, Cryptococcus, Mucor, Fusarium, Scedosporium, and dimorphic fungi (Blastomyces, Histoplasma, and Coccidioides) (69). However, its clinical efficacy as an antifungal drug is yet to be ascertained.

\section{REFERENCES}

1. Schwartz IS, Maphanga TG, Govender NP. Emergomyces: a new genus of dimorphic fungal pathogens causing disseminated disease among immunocompromised persons globally. Curr Fungal Infect Rep. (2018) 12:4450. doi: 10.1007/s12281-018-0308-y

2. Dukik K, Muñoz JF, Jiang Y, Feng P, Sigler L, Stielow JB, et al. Novel taxa of thermally dimorphic systemic pathogens in the Ajellomycetaceae (Onygenales). Mycoses. (2017) 60:296-309. doi: 10.1111/myc.12601

3. Schwartz IS, Govender NP, Sigler L, Jiang Y, Maphanga TG, Toplis B, et al. Emergomyces: the global rise of new dimorphic fungal pathogens. PLoS Pathog. (2019) 15:e1007977. doi: 10.1371/journal.ppat.1007977

4. Jiang Y, Dukik K, Munoz JF, Sigler L, Schwartz IS, Govender NP, et al. Phylogeny, ecology and taxonomy of systemic pathogens and their relatives in Ajellomycetaceae (Onygenales): Blastomyces, Emergomyces, Emmonsia, Emmonsiellopsis. Fungal Divers. (2018) 90:245-91. doi: 10.1007/s13225-018-0403-y

5. Maphanga TG, Birkhead M, Muñoz JF, Allam M, Zulu TG, Cuomo CA, et al. Human blastomycosis in south africa caused by blastomyces percursus

\section{CONCLUSION}

Emergomycosis is a fatal systemic fungal disease among immunocompromised patients in endemic regions and diagnosis is challenging, particularly in resource limited settings. A high index of suspicion is needed, especially in countries where tuberculosis and dimorphic fungal infections are endemic. In absence of consensus guidelines for the treatment of this condition, the IDSA recommendations for management of histoplasmosis and blastomycosis are being followed for emergomycosis. However, mortality still remains very high and the scenario is further complicated by drug-drug interactions, emergence of resistance and intolerance to the available antifungals. The newer drugs, such as amphotericin B cochleate, SUBA-itraconazole, olorofim, fosmanogepix, VT-1598 and AR-12 are a welcome addition to the antifungal armamentarium. Several of these agents have demonstrated good in vitro activity against endemic fungi like Histoplasma, Blastomyces, Coccidioides, and Sporothrix with better tolerability and safety profile. Future studies should focus on evaluating the efficacies of these novel antifungals against Emergomyces spp. which would help in optimizing management and improving patient outcomes.

\section{AUTHOR CONTRIBUTIONS}

ASa and ASh conceptualized the work, reviewed, edited, and validated the final version of the manuscript.

\section{ACKNOWLEDGMENTS}

The authors are thankful to Oxford University Press for giving permission to reproduce clinical images (Figure 1) from the article Clinical Characteristics, Diagnosis, Management, and Outcomes of Disseminated Emmonsiosis: A Retrospective Case Series published in Clinical Infectious Diseases (Vol. 61, Issue 6, Jun 19, 2015), under license no. 4798270046475; Dated: 29/03/2020. and Blastomyces emzantsi sp. nov., 1967 to 2014. J Clin Microbiol. (2020) 58:e01661-19. doi: 10.1128/JCM.01661-19

6. Jiang Y, Tsui CKM, Ahmed SA, Hagen F, Shang Z, Gerrits van den Ende AHG, et al. Intraspecific diversity and taxonomy of Emmonsia crescens. Mycopathologia. (2020) 185:613-27. doi: 10.1007/s11046-020-00475-4

7. Schwartz IS, Lerm B, Hoving JC, Kenyon C, Horsnell WG, Basson WJ, et al. Emergomyces africanus in Soil, South Africa. Emerg Infect Dis. (2018) 24:377-80. doi: 10.3201/eid2402.171351

8. Muñoz JF, McEwen JG, Clay OK, Cuomo CA. Genome analysis reveals evolutionary mechanisms of adaptation in systemic dimorphic fungi. Sci Rep. (2018) 8:4473. doi: 10.1038/s41598-018-22816-6

9. Ashraf N, Kubat RC, Poplin V, Adenis AA, Denning DW, Wright L, et al. Re-drawing the maps for Endemic mycosis. Mycopathologia. (2020) 185:84365. doi: 10.1007/s11046-020-00431-2

10. Danesi P, Falcaro C, Dukik K, Jiang Y, Rizzoli AP, Allavena R, et al. Molecular diagnosis of Emmonsia-like fungi occurring in wild animals. Mycopathologia. (2020) 185:51-65. doi: 10.1007/s11046-019-00353-8

11. Feng $\mathrm{P}$, Yin $\mathrm{S}$, Zhu G, Li M, Wu B, Xie $\mathrm{Y}$, et al. Disseminated infection caused by Emmonsia pasteuriana in a renal transplant 
recipient. J Dermatol. (2015) 42:1179-82. doi: 10.1111/1346-8138. 12975

12. Tang $\mathrm{XH}$, Zhou $\mathrm{H}$, Zhang $\mathrm{XQ}$, Han JD, Gao Q. Cutaneous disseminated emmonsiosis due to Emmonsia pasteuriana in a patient with cytomegalovirus enteritis. JAMA Dermatol. (2015) 151:1263-4. doi: 10.1001/jamadermatol.2015.1792

13. Malik R, Capoor MR, Vanidassane I, Gogna A, Singh A, Sen B, et al. Disseminated Emmonsia pasteuriana infection in India:a case report and a review. Mycoses. (2016) 59:127-32. doi: 10.1111/myc.12437

14. Capoor MR, Mishra N, Kolte S, Singla G, Gogna A, Rudramurthy $\mathrm{S}$, et al. Disseminated Emergomyces pasteurianus infection in India: a case report and a review. Mycopathologia. (2020) 185:193-200. doi: 10.1007/s11046-019-00387-y

15. Gori S, Drouhet E, Gueho E, Huerre M, Lofaro A, Parenti M, et al. Cutaneous disseminated mycosis in a patient with AIDS due to a new dimorphic fungus. J Mycol Med. (1998) 8:57-63.

16. Lavergne R-A, Kandel-Aznar C, Khatchatourian L, Garcia-Hermoso D, Jeddi F, Boutoille D, et al. Emmonsia pasteuriana: une cause rare d'infection fongique chez l'immunodéprimé. J Mycol Med. (2017) 27:e78. doi: 10.1016/j.mycmed.2017.04.025

17. Pelegrín I, Alastruey-Izquierdo A, Ayats J, Cuenca-Estrella M, Cabellos C. A second look at Emmonsia infection can make the difference. Transpl Infect Dis. (2014) 16:519-20. doi: 10.1111/tid.12214

18. Gast KB, van der Hoeven A, de Boer MGJ, van Esser JWJ, Kuijper EJ, Verweij JJ, et al. Two cases of Emergomyces pasteurianus infection in immunocompromised patients in the Netherlands. Med Mycol Case Rep. (2019) 24:5-8. doi: 10.1016/j.mmcr.2019.01.005

19. Wilmes D, Rooms I, Heidemarie L, McCormick Smith I, Haase G, et al. Emergomycosis: case report of a disseminated Emergomyces pasteurianus infection and review of an emerging fungal infection. 52nd Scientific Conference of the German speaking Mycological Society (DMykG) together with the Austrian Society for Medical Mycology (ÖGMM), 6-8 September (2018). Innsbruck, Austria: Mycoses (2018).

20. Kenyon C, Bonorchis K, Corcoran C, Meintjes G, Locketz M, Lehloenya R, et al. A dimorphic fungus causing disseminated infection in South Africa. $N$ Engl J Med. (2013) 369:1416-24. doi: 10.1056/NEJMoa1215460

21. Schwartz IS, Sanche S, Wiederhold NP, Patterson TF, Sigler L. Emergomyces canadensis, a dimorphic fungus causing fatal systemic human disease in North America. Emerg Infect Dis. (2018) 24:758-61. doi: 10.3201/eid2404.171765

22. Wang P, Kenyon C, de Hoog S, Patterson TF, Sigler L. A novel dimorphic pathogen, Emergomyces orientalis (Onygenales), agent of disseminated infection. Mycoses. (2017) 60:310-9. doi: 10.1111/myc.12583

23. Wellinghausen N, Kern WV, Haase G, Rozdzinski E, Kern P, Marre R, et al. Chronic granulomatous lung infection caused by the dimorphic fungus Emmonsia sp. Int J Med Microbiol. (2003) 293:441-5. doi: 10.1078/1438-4221-00281

24. Moodley A, Mosam A, Govender NP, Mahabeer Y, Chateau AV. Emergomyces africanus: the mimicking fungus. Dermatopathology. (2019) 6:157-62. doi: 10.1159/000497608

25. Schwartz IS, Kenyon C, Lehloenya R, Claasens S, Spengane Z, Prozesky $\mathrm{H}$, et al. AIDS-related endemic mycoses in Western Cape, South Africa, and clinical mimics:a cross-sectional study of adults with advanced HIV and recent-onset, widespread skin lesions. Open Forum Infect Dis. (2017) 4:ofx186. doi: 10.1093/ofid/ofx186

26. van Schalkwyk E, Mhlanga M, Maphanga TG, Mpembe RS, Shillubane A, Iyaloo S, et al. Screening for invasive fungal disease using non-culture-based assays among in patients with advanced HIV disease at a large academic hospital in South Africa. Mycoses. (2020) 63:478-87. doi: 10.1111/myc.13071

27. Schwartz IS, Govender NP, Corcoran C, Dlamini S, Prozesky H, Burton $\mathrm{R}$, et al. Clinical characteristics, diagnosis, management and outcomes of disseminated emmonsiosis:a retrospective case series. Clin Infect Dis. (2015) 61:1004-12. doi: 10.1093/cid/civ439

28. Schwartz IS, McLoud JD, Berman D, Botha A, Lerm B, Colebunders R, et al. Molecular detection of airborne Emergomyces africanus, a thermally dimorphic fungal pathogen, in Cape Town, South Africa. PLoS Negl Trop Dis. (2018) 12:e0006174. doi: 10.1371/journal.pntd.0006174

29. Cronjé N, Schwartz IS, Retief L, Bastos ADS, Matthee S, Preiser W, et al. Attempted molecular detection of the thermally dimorphic human fungal pathogen Emergomyces africanus in terrestrial small mammals in South Africa. Med Mycol. (2018) 56:510-3. doi: 10.1093/mmy/myx065

30. Lerm B, Kenyon C, Schwartz IS, Kroukamp H, de Witt R, Govender NP, et al. First report of urease activity in the novel systemic fungal pathogen Emergomyces africanus: a comparison with the neurotrope Cryptococcus neoformans. FEMS Yeast Res. (2017) 17:fox069. doi: 10.1093/femsyr/fox069

31. Osterholzer JJ, Surana R, Milam JE, Montano GT, Chen GH, Sonstein J, et al. Cryptococcal urease promotes the accumulation of immature dendritic cells and a non-protective T2 immune response within the lung. Am J Pathol. (2009) 174:932-43. doi: 10.2353/ajpath.2009.080673

32. Govender NP, Grayson W. Emergomycosis (Emergomyces africanus) in advanced HIV disease. Dermatopathology. (2019) 6:63-9. doi: 10.1159/000495405

33. Grayson W. Infectious diseases of the skin. In: Calonje EJ, Brenn T, Lazar A, Billings S, editors. McKee's Pathology of the Skin With Clinical Correlations, 5th Edn. Philadelphia: Elsevier (2018).

34. Crombie K, Spengane Z, Locketz M, Dlamini S, Lehloenya R, Wasserman S, et al. Paradoxical worsening of Emergomyces africanus infection in an HIVinfected male on itraconazole and antiretroviral therapy. PLoS Negl Trop Dis. (2018) 12:e0006173. doi: 10.1371/journal.pntd.0006173

35. Alanio A, Bretagne S. Difficulties with molecular diagnostic tests for mould and yeast infections:where do we stand? Clin Microbiol Infect. (2014) 20(Suppl 6):36-41. doi: 10.1111/1469-0691.12617

36. Alanio A, Gits-Muselli M, Lanternier F, Sturny-Leclère A, Benazra M, Hamane S, et al. Evaluation of a new Histoplasma spp. reverse transcriptase quantitative PCR assay. J Mol Diagn. (2021) 2021:S1525-1578(21)00061-1. doi: 10.1016/j.jmoldx.2021.02.007

37. Maphanga TG, Britz E, Zulu TG, Mpembe RS, Naicker SD, Schwartz IS, et al. In vitro antifungal susceptibility of yeast and mold phases of isolates of dimorphic fungal pathogen Emergomyces africanus (Formerly Emmonsia sp.) from HIV-infected South African Patients. J Clin Microbiol. (2017) 55:181220. doi: 10.1128/JCM.02524-16

38. Rooms I, Mugisha P, Gambichler T, Hadaschik E, Esser S, Rath PM, et al. Disseminated emergomycosis in a person with HIV infection, Uganda. Emerg Infect Dis. (2019) 25:1750-1. doi: 10.3201/eid2509.181234

39. Rickerts V, Khot PD, Myerson D, Ko DL, Lambrecht E, Fredricks DN. Comparison of quantitative real time PCR with sequencing and ribosomal RNA-FISH for the identification of fungi in formalin fixed, paraffin-embedded tissue specimens. BMC Infect Dis. (2011) 11:202. doi: 10.1186/1471-2334-11-202

40. Springer J, McCormick Smith I, Hartmann S, Winkelmann R, Wilmes D, Cornely $\mathrm{O}$, et al. Identification of Aspergillus and Mucorales in formalinfixed, paraffin-embedded tissue samples: comparison of specific and broadrange fungal qPCR assays. Med Mycol. (2019) 57:308-13. doi: 10.1093/mmy/ myy041

41. Maphanga TG, Naicker SD, Gómez BL, Mhlanga M, Mpembe RS, Schwartz IS, et al. Cross-reactivity of a Histoplasma capsulatum antigen enzyme immunoassay in urine specimens from persons with emergomycosis in South Africa. Med Mycol. (2020) 2020:myaa100. doi: 10.1093/mmy/ myaa100

42. Dukik K, Al-Hatmi AMS, Curfs-Breuker I, Faro D, de Hoog S, Meis JF. Antifungal susceptibility of emerging dimorphic pathogens in the family Ajellomycetaceae. Antimicrob Agents Chemother. (2018) 62:e188617. doi: 10.1128/AAC.01886-17

43. Goughenour KD, Rappleye CA. Antifungal therapeutics for dimorphic fungal pathogens. Virulence. (2017) 8:211-21. doi: 10.1080/21505594.2016.1235653

44. Wheat LJ, Freifeld AG, Kleiman MB, Baddley JW, McKinsey DS, Loyd JE, et al. Clinical practice guidelines for the management of patients with histoplasmosis: 2007 update by the Infectious Diseases Society of America. Clin Infect Dis. (2007) 45:807-25. doi: 10.1086/521259

45. Wiederhold NP. The antifungal arsenal:alternative drugs and future targets. Int $J$ Antimicrob Agents. (2018) 51:3339. doi: 10.1016/j.ijantimicag.2017.09.002

46. Perfect JR. The antifungal pipeline:a reality check. Nat Rev Drug Discov. (2017) 16:603-16. doi: 10.1038/nrd.2017.46

47. Van Daele R, Spriet I, Wauters J, Maertens J, Mercier T, Van Hecke S, et al. Antifungal drugs: what brings the future? Med Mycol. (2019) 57:S32843. doi: $10.1093 / \mathrm{mmy} / \mathrm{myz} 012$ 
48. Thompson GR III, Cadena J, Patterson TF. Overview of antifungal agents. Clin Chest Med. (2009) 30:203-15. doi: 10.1016/j.ccm.2009.02.001

49. Thompson GR III, Wiederhold NP. Isavuconazole:a comprehensive review of spectrum of activity of a new triazole. Mycopathologia. (2010) 170:291313. doi: 10.1007/s11046-010-9324-3

50. Thompson GR III, Rendon A, Ribeiro Dos Santos R, Queiroz-Telles F, Ostrosky-Zeichner L, Azie $\mathrm{N}$, et al. Isavuconazole treatment of cryptococcosis and dimorphic mycoses. Clin Infect Dis. (2016) 63:35662. doi: $10.1093 / \mathrm{cid} / \mathrm{ciw} 305$

51. Hughes CA, Foisy $M$, Tseng A. Interactions between antifungal and antiretroviral agents. Exp Opin Drug Saf. (2010) 9:72342. doi: $10.1517 / 14740331003752694$

52. Schwartz IS, Wasserman S. Itraconazole and antiretroviral therapy:strategies for empiric dosing. Lancet Infect Dis. (2017) 17:1122-3. doi: 10.1016/S1473-3099(17)30568-6

53. Lestner J, Hope WW. Itraconazole:an update on pharmacology and clinical use for treatment of invasive and allergic fungal infections. Exp Opin Drug Metab Toxicol. (2013) 9:911-26. doi: 10.1517/17425255.2013.794785

54. Santangelo R, Paderu P, Delmas G, Chen ZW, Mannino R, Zarif L, et al. Efficacy of oral cochleate-amphotericin B in a mouse model of systemic candidiasis. Antimicrob Agents Chemother. (2000) 44:235660. doi: 10.1128/AAC.44.9.2356-2360.2000

55. Shende P, Khair R, Gaud RS. Nanostructured cochleates: a multi-layered platform for cellular transportation of therapeutics. Drug Dev Ind Pharm. (2019) 45:869-81. doi: 10.1080/03639045.2019.1583757

56. Nield B, Larsen SR, van Hal SJ. Clinical experience with new formulation

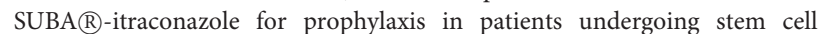
transplantation or treatment for haematological malignancies. J Antimicrob Chemother. (2019) 74:3049-55. doi: 10.1093/jac/dkz303

57. Abuhelwa AY, Foster DJ, Mudge S, Hayes D, Upton RN. Population pharmacokinetic modeling of itraconazole and hydroxyitraconazole for oral SUBA-itraconazole and sporanox capsule formulations in healthy subjects in fed and fasted states. Antimicrob Agents Chemother. (2015) 59:568196. doi: 10.1128/AAC.00973-15

58. Oliver JD, Sibley GEM, Beckmann N, Dobb KS, Slater MJ, McEntee L, et al. F901318 represents a novel class of antifungal drug that inhibits dihydroorotate dehydrogenase. Proc Natl Acad Sci USA. (2016) 113:1280914. doi: $10.1073 /$ pnas. 1608304113

59. Garavito MF, Narváez-Ortiz HY, Zimmermann BH. Pyrimidine metabolism: dynamic and versatile pathways in pathogens and cellular development. J Genet Genomics. (2015) 42:195-205. doi: 10.1016/j.jgg.2015. 04.004

60. Rivero-Menendez O, Cuenca-Estrella $\mathrm{M}$, Alastruey-Izquierdo A. In vitro activity of olorofim (F901318) against clinical isolates of cryptic species of Aspergillus by EUCAST and CLSI methodologies. J Antimicrob Chemother. (2019) 74:1586-90. doi: 10.1093/jac/dkz078
61. Wiederhold NP, Najvar LK, Jaramillo R, Olivo M, Birch M, Law D, et al. The orotomide olorofim is efficacious in an experimental model of central nervous system coccidioidomycosis. Antimicrob Agents Chemother. (2018) 62:e00999-18. doi: 10.1128/AAC.00999-18

62. Shaw KJ, Ibrahim AS. Fosmanogepix: a review of the first-in-class broad spectrum agent for the treatment of invasive fungal infections. J Fungi.(2020) 6:239. doi: 10.3390/jof6040239

63. Viriyakosol S, Kapoor M, Okamoto S, Covel J, Soltow QA, Trzoss M, et al. APX001 and other Gwt1 inhibitor prodrugs are effective in experimental coccidioides immitis pneumonia. Antimicrob Agents Chemother. (2019) 63:e01715-18. doi: 10.1128/AAC.01715-18

64. Graybill JR, Najvar LK, Bocanegra R, Hector RF, Luther MF. Efficacy of nikkomycin $\mathrm{Z}$ in the treatment of murine histoplasmosis. Antimicrob Agents Chemother. (1998) 42:2371-4. doi: 10.1128/AAC.42.9.2371

65. Hector RF, Zimmer BL, Pappagianis D. Evaluation of nikkomycins X and Z in murine models of coccidioidomycosis, histoplasmosis, and blastomycosis. Antimicrob Agents Chemother. (1990) 34:587-93. doi: 10.1128/AAC.34. 4.587

66. Poester VR, Munhoz LS, Larwood D, Martinez M, Stevens DA, Xavier MO. Potential use of Nikkomycin Z as an anti- Sporothrix spp. drug. Med Mycol. (2020) 2020:myaa054. doi: 10.1093/mmy/myaa054

67. Hoekstra WJ, Garvey EP, Moore WR, Rafferty SW, Yates CM, Schotzinger RJ. Design and optimization of highly-selective fungal CYP51 inhibitors. Bioorg Med Chem Lett. (2014) 24:3455-8. doi: 10.1016/j.bmcl.2014. 05.068

68. Wiederhold NP, Shubitz LF, Najvar LK, Jaramillo R, Olivo M, Catano G, et al. The novel fungal Cyp51 inhibitor VT-1598 is efficacious in experimental models of central nervous system coccidioidomycosis caused by Coccidioides posadasii and Coccidioides immitis. Antimicrob Agents Chemother. (2018) 62:e2258-17. doi: 10.1128/AAC.02258-17

69. Koselny K, Green J, DiDone L, Halterman JP, Fothergill AW, Wiederhold $\mathrm{NP}$, et al. The celecoxib derivative AR-12 has broad-spectrum antifungal activity in vitro and improves the activity of fluconazole in a murine model of Cryptococcosis. Antimicrob Agents Chemother. (2016) 60:711527. doi: 10.1128/AAC.01061-16

Conflict of Interest: The authors declare that the research was conducted in the absence of any commercial or financial relationships that could be construed as a potential conflict of interest.

Copyright $\odot 2021$ Samaddar and Sharma. This is an open-access article distributed under the terms of the Creative Commons Attribution License (CC BY). The use, distribution or reproduction in other forums is permitted, provided the original author(s) and the copyright owner(s) are credited and that the original publication in this journal is cited, in accordance with accepted academic practice. No use, distribution or reproduction is permitted which does not comply with these terms. 